\title{
Political Business Cycles at the Municipal Level
}

Linda Gonçalves Veiga

Núcleo de Investigação em Políticas Económicas (NIPE)

Universidade do Minho

Francisco José Veiga

Núcleo de Investigação em Políticas Económicas (NIPE)

Universidade do Minho

\section{Abstract:}

This article tests for the existence of rational political business cycles models using a large and unexplored data set of Portuguese municipalities. The data set is well-suited for this purpose because it provides a high level of detail on expenditure items, because Portuguese municipalities are homogeneous with respect to policy instruments and institutions and follow an exogenously determined election schedule. Estimation results clearly reveal the existence of opportunistic behaviour by local governments. Expenditures increase in pre-election periods, especially on items that are highly visible to the electorate (e.g., highways and streets). This suggests an effort to signal competence and improve chances of re-election.

Keywords: Political business cycles, public finance, local governments.

JEL codes: H72, D72, D78 


\section{Introduction}

This article reports on tests of rational political business cycle (PBC) models using an extensive new data set covering all Portuguese mainland municipalities. With a panel of observations for budget balances and expenditure items over the 1979-2000 periods, it is possible to examine the fiscal choices of local governments over a number of electoral cycles. Thus, we can check whether incumbent politicians increase municipal spending in pre-election periods. Although most previous studies of political business cycles have employed macro-level time series data, the examination of municipal government decisions is motivated by rational political business cycles of the Rogoff and Sibert (1988) type. In those models, incumbents increase spending relative to taxes in pre-election periods as a signal of competence in the presence of imperfect information. This signaling motivation should apply to incumbent politicians at local, as well as national levels. Using this data, we can also investigate if expenditure choices are affected by the timing of national elections and if the opportunistic cycle in spending is influenced by the mayor's ideology, the support she enjoys at the municipal assembly, and by her decision to run for another term in office.

Use of data for Portuguese municipalities ${ }^{1}$ is motivated by the fact that they constitute a very good laboratory to test for the existence of rational political business cycles. First, data on public expenditures are very detailed, allowing for tests of PBC on particular expenditure categories. Second, the institutional structure of local governments and the policy instruments available are the same for all localities, making this panel preferable to one composed of several countries, or states, with different institutions and policy instruments. Third, election dates are fixed and defined exogenously from the perspective of the local authorities, and all municipalities have elections in the same day. Finally, because the data set is large (with a maximum of 278 cross-sections and 22 years of observations), inferences are likely to be more revealing that those obtained with smaller panels of countries and/or states.

Our empirical results provide clear evidence of opportunistic behaviour by mayors (Presidentes de Câmara), evidenced by pre-election increases in expenditure items highly visible to the electorate, such as investment expenditures on overpasses, streets and complementary works and rural roads. Econometric tests also demonstrate that the dimension of the opportunistic cycle in expenditures does not depend on

\footnotetext{
${ }^{1}$ Since there are no states or administrative regions in mainland Portugal, the municipalities are the largest governmental entities below the national government.
} 
whether the mayor's party has a majority of deputies in the municipal assembly or on whether the incumbent runs for another term in office. However, the cycle's magnitude seems to be influenced by ideology; namely left-wing oriented mayors tend to behave more opportunistically than right-wing ones.

The article is organized as follows. The next section briefly reviews the literature on political business cycles. Section 3 presents a short digression on municipalities and describes the dataset. The empirical strategy used to investigate the impact of elections on municipal budgets and expenditures is explained in section 4 and the results obtained are presented in section 5. Finally, conclusions are reported in section 6.

\section{Political business cycles and municipal governments}

The theory of political business cycles (PBC) originated with Nordhaus (1975), who proposed a model in which incumbent politicians would manipulate the economy to gain electoral advantage. The model presumed that expansionary monetary and fiscal policies would produce a pre-election boom, lowering the unemployment rate, and that myopic voters would respond by supporting the incumbent party with a favorable vote. Given the formulation of the model's expectational Phillips curve, inflationary consequences of the pre-election expansion were largely delayed until after the election, when policy would switch to a more contractionary stance. The Nordhaus model generated much interest and research, but ultimately was a victim of the rational expectations revolution. Nordhaus assumed that voters' expectations were formed adaptatively; i.e., they were based on what voters had recently observed. Pre-election stimulus created "favorable" conditions only because the public failed to anticipate the stimulus and its ultimate consequences. In essence, voters were repeatedly tricked in successive electoral cycles.

In the years following Nordhaus's contribution, the assumption of adaptative expectations has become regarded as untenable in economic theory; the idea that voters would be tricked in the same fashion in repeated elections seems especially improbable. Instead, the assumption of rational expectations, which rules out systematic expectational errors, has become the norm. However, the political business cycle model did not die, but was rehabilitated in a rational expectations environment. Rogoff and Sibert (1988) developed an explanation for the PBC in which asymmetric information replaced voter myopia in explaining electoral cycles in economic policies. In their model, voters have rational expectations, but are unsure of the "competence" of 
politicians (here competence refers to an ability to produce public output with fewer inputs; i.e., at lower cost). Their model can produce an equilibrium in which incumbent politicians increase government spending in pre-election periods in an effort to signal competence. The Rogoff-Sibert model was a welcome contribution for researchers with an empirical interest in political business cycles. Although the implications of the model for cycles in outcomes (as opposed to policies) were ambiguous, the possibility existed, and the necessity for the adaptative expectations assumption was obviated. ${ }^{2}$

Most empirical research on political business cycles has made use of nationallevel data on elections, policies, and economic outcomes. For research based on the Nordhaus model, this was a natural consequence of the development of the theory. The model posited that voters looked at macroeconomic conditions, specifically unemployment and inflation, and that politicians controlled them. Naturally, macroeconomic variables were the object of empirical studies of the PBC as well. With the arrival of the Rogoff-Sibert reconstruction, empirical research did not fundamentally change its direction. The existence of the Rogoff and Sibert (1988) model provided justification for continued interest in the political business cycle, but its major effect was to provide improved theoretical underpinnings rather than to change the way in which political business cycle studies were empirically implemented.

Importantly, the Rogoff-Sibert model is distinguished by the assumption that voters evaluate efficiency in public production. At the local government level, production of public services like fire protection, education, and public safety is a principal activity; it follows that the Rogoff-Sibert model should apply at local governmental levels. It is probably more difficult to argue that voters try to assess "efficiency" in production of national defense, foreign affairs, income redistribution, or legal institutions, which are important concerns of national governments. Thus, the Rogoff-Sibert model is not only applicable to the behavior of local governments; it may be most applicable at that level. In fact, already at the beginning of the 1990's Rogoff highlighted the advantages of research on state or local governments:

"The equilibrium political budget cycle theory suggests that it would be more promising to focus empirical research on testing for electoral cycles in taxes, transfers, and government consumption spending. For

\footnotetext{
2 Other important early contributions to the rational opportunistic business cycles literature were Cukierman and Meltzer (1986), Rogoff (1990) and Person and Tabellini (1990).
} 
these variables, one can also look at data for state and local elections, instead of concentrating solely on the small number of observations available for national elections" (Rogoff, 1990: 33-34).

In contrast, the Nordhaus model typically would not apply well to municipalities. Local governments have little ability to stimulate employment through expenditures, since much of the employment impact of added spending will be felt outside of the locality. The impact of local decisions on inflation rates is even smaller. ${ }^{3}$

One of the first studies that followed Rogoff's suggestion was Blais and Nadeau (1992), which tested the existence of political fiscal cycles in ten Canadian provinces, from 1951 to 1984 . Results suggested the existence of a short electoral cycle, only in the year before the election, and mainly visible on social services and road expenditures. According to these authors, there are no substantial differences in the magnitude of local governments' opportunistic behaviour that can be attributable to ideology, the duration of terms, or tenure in office.

Using data from local governments in Israel, Rosenberg (1992) presented a model where the value of public expenditures over a term in office is influenced by the re-election motive and also by the personal financial situation of the incumbent if he loses the election. ${ }^{4}$ Tests implemented on development expenditures of ten Israeli towns, using annual data from 1964 to 1982, confirmed his hypothesis.

Some other studies have been published about countries including the U.S., Germany, and Sweden. ${ }^{5}$ However, the Portuguese case has received little attention at both at the national and sub-national levels. ${ }^{6}$ Since Portugal is a relatively new democracy, the problem of an insufficient number of observations to perform aggregated analysis is more severe than in most countries. This provides added motivation for a focus on municipalities.

\footnotetext{
${ }^{3}$ The Nordhaus model is not completely irrelevant for local governments. Local government expenditures can have effects on local unemployment, for example, especially if labor is immobile.

${ }^{4}$ In this case, public expenditure manipulation has in mind an increase in employment opportunities in the private sector, or even a direct transfer of income trough the allocation of contracts to firms in the private sector. According to the model, incumbents that decide not to run again for office increase public expenditures before the elections more than those that try to be re-elected.

${ }^{5}$ For an extended and updated revision of the empirical literature about the U.S. see Besley and Case (2003). For studies about Germany see Seitz (2000) and Galli and Rossi (2002). For Sweden see Petterson-Lidbom (2001).

${ }^{6}$ Regarding local governments, see the working papers of Baleiras and Costa (2001), and Veiga (2002).
} 


\section{Portuguese municipalities: brief characterization and sources of statistical data}

This section presents some background information on institutional practices governing public finance in Portuguese municipalities. Democracy was re-established in Portugal in April 25, 1974 after 48 years of dictatorship. ${ }^{7}$ Portuguese municipalities were formally established in the 1976 Constitution and the first municipal elections took place in December 1976. The panel of data we use comprises all mainland municipalities (currently 278), from 1979 to 2000, covering six electoral periods.

Portuguese local governments are responsible for improving the well-being of the populations that live in their territories. They promote social and economic development, territory organization, and supply local public goods (water and sewage, energy, transportation, housing, healthcare, education, culture, sports, environmental preservation, and public safety). ${ }^{8}$

There are no differences in budgeting rules and institutions across Portuguese mainland municipalities, ${ }^{9}$ however, the law regulating local public finances changed several times during the period considered. ${ }^{10}$ Municipalities are financially autonomous. They have their own employees and assets. Each year the executive branch of the municipality (town council) proposes a local budget and the plan of activities to the legislative branch (municipal assembly). Budgets adopted by the municipal assembly do not require the agreement of the national government. As part of the general government sector, local authorities are, however, subject to several control mechanisms by central government agencies. These, limit their access to revenue and their expenditure choices.

Political business cycles are more likely to occur in expenditure categories where the timing of implementation is controlled by the mayor and where the expenditures are visible to the electorate. Local Portuguese politicians have more freedom to manipulate municipalities' expenditures than revenues. ${ }^{11}$ Therefore, our analysis concentrates on the former and, in particular, on capital expenditures. Current

\footnotetext{
7 The number of observations for studies intended to analyze the behavior of Portuguese central governments is small. Since the end of the dictatorship there have been only 10 legislative elections in Portugal. Research on local governments provides many more degrees of freedom.

${ }^{8}$ Law 159/99 defines the areas of intervention of Portuguese local governments.

${ }^{9}$ Overseas municipalities, belonging to the islands of Madeira and Azores, are treated differently from those in the mainland.

${ }^{10}$ Law 1/79, Decree-Law 98/84, Law 1/87 and, currently, Law 46/98.

${ }^{11}$ Transfers from the Central Administration and the E.U. represent a very important source of funding for municipalities.
} 
expenditure decisions are subject to greater rigidity. In the current expenditures category, items such as salaries do not have enough flexibility to be changed before elections because they are regulated by rigid labour contracts, both in terms of duration and wage rates.

Capital expenditures in Portuguese municipalities include investment expenditures implemented by the municipality and capital transfers to the counties (freguesias). Investment expenditures are divided into seven categories, some with subcomponents: (1) acquisition of land, (2) housing, (3) other buildings, (4) miscellaneous construction, (5) transportation material, (6) machinery equipment, and (7) other investments. "Other buildings" include: (3.1) sports, recreational and schooling infrastructures; (3.2) social equipment; and (3.3) other. The "Miscellaneous constructions" category is composed of the following items: (4.1) overpasses, streets and complementary work; (4.2) sewage; (4.3) water treatment and distribution; (4.4) rural roads; (4.5) infrastructures for solid waste treatment; and (4.6) other.

Data on the municipalities' local accounts and population were obtained from the local authority's (Direç̧ão Geral das Autarquias Locais) annual publication called Finanças Municipais (Municipal Finances). This report exists from 1979 to 1983 and from 1986 to 2000 . For the two missing years data was obtained directly from the municipalities' official accounts and is incomplete: we have 150 observations for 1984 and 154 for 1985. Data on the area of municipalities was acquired from the Marktest's Sales Index dataset, the consumer price indexes were taken from the IMF's International Financial Statistics, the percentages of the population under 15 and over 65 years old were obtained in the 1970, 1981 and 1991 Census and in the Anuário Estatístico Regional (Regional Statistical Yearbook) of the Portuguese Institute of Statistics (INE).

Political data, namely election dates and municipal electoral results, were obtained from the National Electoral Commission (Comissão Nacional de Eleições) and from the Technical Staff for Matters Concerning the Electoral Process (Secretariado Técnico dos Assuntos para o Processo Eleitoral) of the Internal Affairs Ministry. It is worth noting that election dates are defined exogenously from the perspective of the local authorities. Since the re-establishment of Democracy in 1974, there were local elections in 1976, 1979, 1982, 1985, 1989, 1993, 1997 and 2001, always in December. 


\section{Model specification}

The first empirical model to be implemented uses the budget balance (per capita, at 1995 prices) as the dependent variable. ${ }^{12}$ Since mayors have little control over their municipality's revenues, it is possible that expenditures are more subject to political manipulation than budget balances. Thus, a model that has real per capita total expenditures, TotExp, as the dependent variable was estimated. But, since current expenditures are strongly conditioned by salaries, it is likely that the evidence for political business cycles is greater for capital expenditures, CapExp, and, among these, for investment expenditures, InvExp (both expressed in real terms, per capita). Thus, equations for these types of expenditures were also estimated.

The following explanatory variables are used in these four models:

- Lagged values of the dependent variable, in order to account for the autoregressive component of the time series;

- TotTransf $f_{i t}$ is the total of real per capita transfers that the municipality $i$ receives during the year $t$. Given their weight of roughly $70 \%$ in the municipalities' revenues, it is anticipated that transfers have a strong positive effect on total expenditures, TotExp.

- CapTransf $f_{i t}$, the real per capita capital transfers that municipality $i$ receives during year $t$, are used instead of TotTransfit in the equations for capital expenditures (CapExp) and investment expenditures (InvExp). ${ }^{13}$ Transfers also reflect, and allow us to control for, the macroeconomic performance of the country. We anticipate that greater transfers allow for greater expenditures;

- ElectionYear it $_{\text {is }}$ a dummy variable that takes the value of 1 in municipal election years and zero in non-election years. With this variable we test the hypothesis that municipal budget deficits and expenditures are higher in election years. Thus, a negative estimated coefficient is expected for ElectionYear in the equation for the BudgetBalance and positive signs are expected in the equations for TotExp, CapExp and InvExp;

\footnotetext{
${ }^{12}$ For each municipality, the budget balance was divided by the consumer price index for the base year (1995) and, then, by its population. The budget balance, based on public accounting, is calculated according to the methodology of the General Direction of the Budget (Direcção Geral do Orçamento) of the Ministry of Finance, which excludes the transactions in financial assets and liabilities from the totals of revenues and expenditures.

${ }^{13}$ Capital transfers account, on average, for $72 \%$ of capital expenditures. Descriptive statistics are shown in Table 1.
} 
- Right $_{i t}$ is a dummy variable that takes the value of 1 when the mayor (Presidente de Câmara) of municipality $i$ belongs to a right-wing party (PPD/PSD - Social Democratic Party or CDS/PP - People's Party) and zero when she belongs to a left-wing party (PS - Socialist Party, PCP/CDU - Portuguese Communist Party or PRD - Democratic Renewal Party). With this variable we test for the existence of ideological cycles (see Hibbs, 1977) in the budget balances and expenditures of Portuguese mainland municipalities;

- Since real per capita municipal expenditures may be affected by variables such as the age structure of the population, population density, geographical location, population, etc., the following control variables were included in all estimations:

○ $\%$ Pop $<15$ - Percentage of the population under 15 years old;

○ $\%$ Pop $>65$ - Percentage of the population over 65 years old;

○ PopDens - Population density;

- Coastline - Dummy variable that takes the value of 1 for municipalities that belong to districts (Distritos) along the coastline (the richest and most developed ones), and zero for those that belong to districts located in the interior of the country;

- PopCat - Population category: 1 - Lisbon and Porto; 2 - other municipalities, with population over 40000;3 - municipalities with population between 10000 and 40000; 4 - remaining municipalities. ${ }^{14}$

\section{(Table 1, Page 17)}

The empirical model can be summarized as follows:

$$
y_{i t}=\sum_{j=1}^{p} \alpha_{j} y_{i, t-j}+\mathbf{X}_{i, t}^{\prime} \boldsymbol{\beta}+v_{i}+\varepsilon_{i t} \quad i=1, \ldots, N \quad t=1, \ldots, T_{i}
$$

where $y_{i t}$ is the dependent variable and $p$ is its number of lags included in the model, $\mathbf{X}_{i t}^{\prime}$ is a vector of explanatory variables, $\boldsymbol{\beta}$ is a vector of parameters to be estimated, $v_{i}$ is the individual effect of municipality $i$, and $\varepsilon_{i t}$ is the error term.

Given the presence of individual effects, $v_{i}$, the model referred to above can be estimated assuming that those effects are either fixed or random. But, the lagged value

\footnotetext{
${ }^{14}$ These population categories are used in the legislation to determine the mayors' salaries.
} 
of the dependent variable would be correlated with the error term, $\varepsilon_{i t}$, even if the latter is not serially correlated. This implies inconsistent estimates of the model, when there is a clear dominance of cross sections over time periods in the sample. ${ }^{15}$ This is exactly what happens in our panel, in which the number of municipalities $(\mathrm{N}=278)$ is about 12 times larger than the number of years available $(\mathrm{T}=22)$.

Arellano and Bond (1991) developed a Generalized Method of Moments (GMM) estimator that solves the problems noted above. First differencing (1) removes the individual effects $\left(v_{i}\right)$ and produces an equation that is estimable by instrumental variables:

$$
\Delta y_{i t}=\Delta \sum_{j=1}^{p} \alpha_{j} y_{i, t-j}+\Delta \mathbf{X}_{i, t}^{\prime} \boldsymbol{\beta}+\Delta \varepsilon_{i t} \quad i=1, \ldots, N \quad t=1, \ldots, T_{i}
$$

The valid instruments are: levels of the dependent variable, lagged two or more periods $\left(y_{i l}, \ldots, y_{i t-2}\right)$; levels of the endogenous variables, lagged two or more periods $\left(x_{i 1}, \ldots, x_{i t-2}\right)$; levels of the pre-determined variables, lagged one or more periods $\left(x_{i 1}, \ldots, x_{i t-}\right.$ 1); and the levels of the exogenous variables, current or lagged $\left(x_{i 1}, \ldots, x_{i t}\right)$ or, simply, the first differences of the exogenous variables $\left(\Delta x_{i t}\right)$.

More moment conditions are available if we assume that the explanatory variables $\left(x_{i t}\right)$ are uncorrelated with the individual effects $\left(v_{i}\right)$. In this case, the first lags of these variables $\left(x_{i t-1}\right)$ can be used as instruments in the levels equation. The estimation then combines the set of moment conditions available for the firstdifferenced equations with the additional moment conditions implied for the levels equations.

If the level of an explanatory variable $x_{i t}$ is correlated with the individual effects $v_{i}$ but its first-differences $\left(\Delta x_{i t}\right)$ are not, lagged values of the first-differences $\left(\Delta x_{i t-1}\right)$ can be used as instruments in the equation in levels (Arellano and Bover, 1995). Lagged differences of the dependent variable $\left(\Delta y_{i, t-1}\right)$ may also be valid instruments for the levels equations. Blundell and Bond (1998) show that this extended GMM estimator is preferable to that of Arellano and Bond (1991) when the dependent variable and/or the independent variables are persistent. ${ }^{16}$

\footnotetext{
${ }^{15}$ See Arellano and Bond (1991) and Baltagi (2001).

${ }^{16}$ Since there is some persistence of expenditures and transfers, it is appropriate to estimate this systemGMM. Furthermore, difference Sargan tests indicate that, for our data, the system-GMM is preferable to the GMM that only includes the first-differenced equations.
} 


\section{Empirical results}

The estimation results of the models described in the previous section using the method system-GMM for linear dynamic panel data models are shown in Table 2. It presents the two-step results, using robust standard errors corrected for finite samples. ${ }^{17}$ T-statistics are presented between parentheses and the degree of statistical significance is signalled with asterisks. The number of observations and municipalities is reported at the foot of the table. ${ }^{18}$

\section{(Table 2, Page 18)}

The first lag of the dependent variable is always statistically significant, and it was necessary to include a second lag in the investment expenditures equation. ${ }^{19}$ As anticipated, the greater the transfers received by a municipality in a given year, the greater are its expenditures: the estimated coefficients associated with TotTransf and CapTransf have positive signs in the last three equations. ${ }^{20}$

There is strong evidence of rational opportunistic cycles for the four dependent variables considered in Table 2, as ElectionYear is always statistically significant and correctly signed. Thus, in municipal election years there are larger budget deficits and higher total, capital and investment expenditures than in the other years of the electoral cycle. As anticipated, the empirical evidence is relatively weak for the budget balance and for total expenditures (for which ElectionYear is only marginally statistically significant) and much greater for capital and investment expenditures. ${ }^{21}$ Results indicate

\footnotetext{
${ }^{17}$ Although it is more common to present the one-step results because the two-step standard errors are generally biased downwards, that problem does not apply to our case, since the econometric software PcGive 10.2 uses the finite-sample correction suggested by Windmeijer (2000). Thus, we present the twostep results, as these have the advantage of being consistent in the presence of heteroskedasticity. In all models, all available instruments were used.

18 When taking lags and first-differences, the observations for three municipalities created in 1997 (Odivelas, Trofa and Vizela) are dropped, leading to a panel of 275 municipalities and 20 years of observations.

${ }^{19}$ The choice of the number of lags to include was based on their statistical significance and on the need to avoid second order autocorrelation of the residuals. Although the second lag of InvExp is not statistically significant, there is second order autocorrelation of the residuals when it is not included.

${ }^{20}$ Although transfers are exogenous relative to expenditures, their levels are correlated with the individual effects. Thus, the once lagged first differences of transfers were used as instruments in the equation in levels.

${ }^{21}$ A model for current expenditures was also estimated. Results confirmed our hypothesis that they were not subject to opportunistic manipulation, given their greater inertia. Nevertheless, we found evidence that left-wing oriented mayors spend more in current expenditures than right-wing ones. These results are available from the authors upon request.
} 
that, holding all else equal, investment expenditures increased by 2170 Portuguese escudos (PTE) ${ }^{22}$ of 1995 per capita in the election year, a relative increase (compared to the sample mean) of $6.8 \%$. Capital expenditures increased by 1138 real escudos (1995 base year) in the election year (a relative increase of $3.2 \%$ ). ${ }^{23}$

There is some evidence that ideology affects spending patterns. Deficits and capital expenditures are greater for right-wing oriented mayors, total expenditures are greater for left-wing oriented mayors, and there is no evidence of ideological effects in investment expenditures. Given the diversity of results and the weak statistical significance of estimated coefficients, it is not possible to draw general conclusions about the character of ideological effects in municipal finances.

Some control variables help explain the differences among municipalities in the behaviour of budget balances and expenditures: municipalities where the percentage of the population under 15 years old is greater have higher surpluses, lower total expenditures and higher investment expenditures; a greater percentage of the population over 65 years old is associated with greater deficits, but does not seem to affect expenditures; budget balances and expenditures do not seem to be affected by the population density; municipalities in districts along the coastline have greater expenditures per capita, but do not show different budget balances from the municipalities in the interior; municipalities with smaller population have lower total per capita expenditures, but do not exhibit statistically significant differences from the most populous ones regarding budget balances and capital and investment expenditures.

In the estimations whose results are shown in Table 3, we tested whether the magnitude of the opportunistic cycle in investment expenditures depends on the mayor's ideology, the support she enjoys in the municipal assembly, or on running for another term in office. ${ }^{24}$ In column 1 , the variable ElectionYear was interacted with dummy variables representing the mayor' ideology: Right and Left (=1-Right). Results suggest that all mayors behave opportunistically, but left-wing oriented ones increase their expenditures in the election year by a higher amount than right-wing ones: the

\footnotetext{
${ }^{22} 2170$ PTE $=10.82$ euro. The conversion rate is: 1 euro $=200.482$ PTE.

${ }^{23}$ The relative changes for the budget balance and total expenditures are of $-24 \%$ and $2.6 \%$, respectively. Although the increase in the deficit indicates a strong opportunistic effect, this results should be interpreted with caution, as the estimated coefficient is only marginally statistically significant.

${ }^{24}$ The five control variables were included in all estimations, but their coefficients and t-statistics are not shown in order to economize space. Furthermore, the objective of this study is to test for the existence of political business cycles, which does not require a detailed analysis of results regarding the control variables.
} 
estimated coefficient associated with ElectionYear*Left is more than twice that of Election Year* ${ }^{*}$ ight. $^{25}$

\section{Table 3, Page 19}

In column 2, we checked whether expenditures and the magnitude of the opportunistic cycle would be different when the mayor had the support of a majority of deputies in the municipal assembly. The dummy variable Majority was included in the model, and it takes the value of 1 when the mayor's party has a majority of deputies in the municipal assembly, and zero otherwise. Additionally, the variable ElectionYear was interacted with the variables Majority and Minority (=1-Majority). Results indicate that a majority induces greater investment expenditures (about 926 escudos per capita), but does not affect the magnitude of the opportunistic behaviour. ${ }^{26}$

Rosenberg's (1992) hypothesis that incumbents that do not run for another term in office generate a greater opportunistic cycle than those that do is tested in column 3 . ElectionYear was interacted with the dummy variables Recand, which equals 1 when the mayor runs for another term and zero when she does not, and NoRecand (=1Recand). Since a Wald test does not reject the equality of the estimated coefficients, our results do not confirm the hypothesis and empirical results obtained by Rosenberg (1992) for Israel nor the more conventional hypothesis that a "lame duck" has little incentive to produce a political business cycle.

Considering that some investments may take several months to be concluded, one should expect incumbents to start increasing investment expenditures in the year before elections, in order to signal greater competency to the electorate. We tested that hypothesis by adding to the model of the last column of Table 2 the dummy variable YearBeforeElection, which equals 1 in the year before municipal elections and zero in the remaining years. As expected, this variable is statistically significant and has a smaller estimated coefficient than ElectionYear ${ }^{27}$ (see column 4 of Table 3). The model of column 5 adds the dummy variable YearLegElection, which equals 1 in a year of national legislative elections and zero in the other years. Here, we test the hypothesis

\footnotetext{
${ }^{25}$ A Wald test clearly rejects the equality of estimated coefficients.

${ }^{26}$ A Wald test does not reject the equality of the coefficients associated with ElectionYear*Majority and ElectionYear*Minority.

${ }^{27}$ A Wald test rejects the equality of estimated coefficients.
} 
that mayors increase expenditures in years of legislative elections to promote a better outcome for their parties at the national level. The results support this hypothesis.

Like Table 2, Table 3 shows little evidence of ideological effects in investment expenditures: the variable Right is only marginally statistically significant in the estimation of column 1 and is not significant in the other estimations.

The next step of the empirical analysis was to determine which types of investment expenditures show the greatest sensitivity to the electoral calendar.. The model of column 4 of Table 3 was estimated for the seven components of investment expenditures (see Table 4). There is evidence of opportunistic cycles for investments in Other Buildings, Miscellaneous Constructions and Other Investments, for which there are increases in the election year (relative to the sample mean) of $13.6 \%, 11.5 \%$ and $16.6 \%$, respectively. ${ }^{28}$ For Miscellaneous Constructions, the increase in expenditures starts one year before elections. Concerning partisan effects, right-wing oriented incumbents tend to spend relatively more on Acquisition of Land and Miscellaneous Constructions (relative increases of $24.3 \%$ and $4.9 \%$, respectively), while left-wing ones spend relatively more on Transportation Material and Machinery and Equipment (relative increases of $11.6 \%$ and $14.6 \%$, respectively).

\section{(Table 4, Page 20)}

Given the strong evidence of the existence of political business cycles in the components of Other Buildings and of Miscellaneous Constructions, ${ }^{29}$ we decided to analyze their sub-components. In order to economize on space, only the results for the sub-components for which there is evidence of opportunistic cycles are presented in Table $5 .{ }^{30}$ Concerning Other Buildings, that only happens for the sub-component Other (which has a weight of 53\%), for which expenditures increase in the election year and, slightly less in the year before (increases of $21.6 \%$ and $17.6 \%$ relative to the sample mean). Concerning the subdivisions of Miscellaneous Constructions, there is clear evidence of opportunistic cycles in Overpasses, streets and complementary works,

\footnotetext{
${ }^{28}$ Expenditures on Transportation Material and Machinery and Equipment decrease in election years. The opportunistic behavior seems to lead not only to an increase in expenditures in general, but also to money transfers from investment components less visible by the electorate to those with greater visibility.

${ }^{29}$ These are the two most important components of investment expenditures, as they jointly account for about $83 \%$ of the total (Other Investments $=17.3 \%$ and Miscellaneous Constructions $=65.6 \%$ ).

${ }^{30}$ The results for the other sub-components are available upon request.
} 
Rural roads, and Other, with increases, relative to the mean, of $14.8 \%, 16.4 \%$ and $36.8 \%$, respectively. It is worth noting that these three items account for around $69 \%$ of the expenditures in miscellaneous constructions. For the first and last of these subcomponents, expenditures also increase in the year prior to the election year, although by a smaller amount (relative increases of $10.6 \%$ and $27.4 \%$, respectively). There is no evidence of ideological effects for the sub-components of investment expenditures included in Table 5, as the dummy variable Right is never statistically significant.

(Table 5, Page 21)

\section{Conclusions}

Empirical results provide clear evidence of political business cycles in Portuguese municipalities. The finding of such cycles at the local level provides support for models of rational opportunistic cycles like that of Rogoff and Sibert (1988). In such models, incumbent politicians manipulate economic policy instruments in order to reveal greater competence shortly before elections. There is clear evidence that municipal budget deficits and expenditures, especially investment expenditures, increase in election years and, sometimes, in the year before. This opportunistic behaviour focuses on investment expenditures that are highly visible to the electorate, such as Other Buildings (particularly in the sub-component Other) and Miscellaneous Constructions (specially in Overpasses, streets and complementary works, Rural roads and Other). This suggests the intention to signal greater competence in pre-election periods. ${ }^{31}$ The magnitude of the cycle does not seem to depend on the support the mayor enjoys in the municipal assembly, nor on the decision to run for another term in office, but left-wing oriented incumbents tend to be more opportunistic than right-wing ones. As for ideological cycles, it is hard to identify general tendencies, given the inconsistency of the results for budget balances, total expenditures and capital expenditures. For investment expenditure and for most of its components, there is no evidence of partisan effects.

\footnotetext{
${ }^{31}$ In future research we wish to analyze whether these increases in deficits and expenditures before elections influence election results. Studies performed at the aggregate level, Veiga and Veiga (2004a and 2004b), allow us to conclude that both unemployment and inflation affect the vote intentions of the Portuguese and the popularity of the main political entities.
} 
Politically-induced fluctuations in expenditures lead to inefficiencies in the allocation of resources, which are harmful to the national economy. If such cycles could be prevented by way of new or tougher rules on the management of municipal finances, expressed in limits to deficits and accumulation of debt, the result should be an improvement in overall welfare.

\section{Acknowledgements}

The authors wish to thank the Portuguese Foundation for Science and Technology (FCT) for funding the project "Voters, policymakers and the economy" (POCTI/2001/ECO/37457) and Henry Chappell and Martin Paldam for helpful comments. The article also benefited from the efficient research assistance of César Coelho, Cláudia Ribeiro and Liliana Veiga.

\section{References}

Arellano, M., Bond, S., 1991. Some tests of specification for panel data: Monte Carlo evidence and an application to employment equations. The Review of Economic Studies 58, 277-297.

Arellano, M., Bover, O., 1995. Another look at the instrumental variable estimation of error-component models. Journal of Econometrics 68, 29-51.

Baleiras, R., Costa, J.S., 2001. To be or not to be in office again, that is the question political business cycles with local governments. Working Paper, Universidade Nova de Lisboa - Portugal.

Baltagi, B.H., 2001. Econometric Analysis of Panel Data, $2^{\text {nd }}$ ed., John Wiley \& Sons, Chichester.

Besley, T., Case, A., 2003. Political institutions and policy choices: evidence from the United States. Journal of Economic Literature XLI(1), 7-73.

Blais, A., Nadeau, R., 1992. The electoral budget cycle. Public Choice 74, 389-403.

Blundell, R., Bond, S., 1998. Initial conditions and moment restrictions in dynamic panel data models. Journal of Econometrics 87, 115-143.

Cukierman, A., Meltzer, A.H., 1986. A positive theory of discriminatory policy, the costs of democratic government and the benefits of a constitution. Economic Inquiry 24, 367-388. 
DGAL, 1979-1983, 1986-2000. Finanças Municipais, Direcção Geral das Autarquias Locais (DGAL), Lisbon.

Galli, E., Rossi, S., 2002. Political budget cycles: the case of the Western German Länder. Public Choice 110, 283-303.

Hibbs, D., 1977. Political parties and macroeconomic policy. The American Political Science Review 7, 1467-1487.

Nordhaus, W., 1975. The political business cycle. Review of Economic Studies 42, 16990.

Person, T., Tabellini, G., 1990. Macroeconomic Policy, Credibility and Politics, Harvood Academic Publishers, London.

Pettersson-Lidbom, P., 2001. An empirical investigation of the strategic use of debt. Journal of Political Economy 109(3), 570-583.

Rogoff, K., 1990. Equilibrium political budget cycles. American Economic Review 80, 21-36.

Rogoff, K., Sibert, A., 1988. Elections and macroeconomic policy cycles. Review of Economics Studies 55, 1-16.

Rosenberg, J., 1992. Rationality and the political business cycle: The Case of Local Government. Public Choice 73, 71-81.

Seitz, H., 2000. Fiscal policy, deficits and politics of subnational governments: The case of the German Laender. Public Choice 102, 183-218.

Veiga, L.G., 2002. The political economy of local governments' Expenditures. NIPE Working Paper 8/2002.

Veiga, L.G., Veiga, F.J., 2004a. Popularity functions, partisan effects and support in Parliament. Economics \& Politics 16(1), 101-115.

Veiga, L.G., Veiga, F.J., 2004b. The determinants of vote intentions in Portugal. Forthcoming in Public Choice 118(3-4).

Windmeijer, F., 2000. A finite sample correction for the variance of linear two-step GMM estimators. Institute of Fiscal Studies Working Paper Series No W00/19. 
Table 1: Descriptive Statistics

\begin{tabular}{|c|c|c|c|c|c|}
\hline Variables & N.Obs. & Average & $\begin{array}{l}\text { Standard } \\
\text { Deviation } \\
\end{array}$ & Minimum & Maximum \\
\hline \multicolumn{6}{|l|}{ Budget balance and expenditure items: } \\
\hline Budget balance & 5809 & -3.51 & 14.71 & -210.92 & 185.44 \\
\hline Total expenditures & 5797 & 68.49 & 42.25 & 2.29 & 841.33 \\
\hline Capital expenditures & 5749 & 36.04 & 24.48 & .72 & 287.96 \\
\hline Investment expenditures & 5743 & 31.81 & 22.51 & 1.78 & 288.51 \\
\hline Acquisition of land & 5472 & .91 & 1.84 & 0 & 40.99 \\
\hline Housing & 5473 & 1.89 & 4.64 & 0 & 100.98 \\
\hline Other buildings & 4449 & 5.51 & 6.40 & 0 & 80.65 \\
\hline Sports, recreational and schooling facilities & 5473 & 1.98 & 3.71 & 0 & 59.73 \\
\hline Social equipment & 5468 & .32 & 1.37 & 0 & 41.75 \\
\hline Other & 4424 & 2.94 & 4.62 & 0 & 61.36 \\
\hline Miscellaneous constructions & 4449 & 20.89 & 17.87 & 0 & 214.70 \\
\hline $\begin{array}{l}\text { Overpasses, streets and complementary } \\
\text { works }\end{array}$ & 5470 & 4.41 & 5.83 & 0 & 84.23 \\
\hline Sewage & 4450 & 2.38 & 3.90 & 0 & 69.10 \\
\hline Water treatment and distribution & 4450 & 2.95 & 4.91 & 0 & 100.28 \\
\hline Rural roads & 5474 & 5.91 & 8.79 & 0 & 152.86 \\
\hline Infrastructures for solid waste treatment & 4442 & .22 & 2.08 & 0 & 98.91 \\
\hline Other & 4175 & 4.02 & 6.88 & 0 & 122.25 \\
\hline Transportation material & 4449 & .99 & 1.32 & 0 & 15.64 \\
\hline Machinery and equipment & 5475 & 1.91 & 2.01 & 0 & 25.79 \\
\hline Other investments & 5195 & .85 & 2.87 & 0 & 52.99 \\
\hline \multicolumn{6}{|l|}{ Transfers: } \\
\hline Total transfers & 5664 & 50.89 & 38.87 & 4.53 & 443.29 \\
\hline Capital transfers & 5741 & 26.06 & 19.48 & 3.04 & 249.74 \\
\hline \multicolumn{6}{|l|}{ Political variables: } \\
\hline ElectionYear & 6116 & .27 & .44 & 0 & 1 \\
\hline YearBeforeElection & 6116 & .27 & .44 & 0 & 1 \\
\hline Right & 6049 & .47 & .50 & 0 & 1 \\
\hline ElectionYear*Right & 6049 & .13 & .34 & 0 & 1 \\
\hline ElectionYear*Left & 6049 & .14 & .35 & 0 & 1 \\
\hline Majority & 6049 & .59 & .49 & 0 & 1 \\
\hline ElectionYear*Majority & 6049 & .15 & .36 & 0 & 1 \\
\hline ElectionYear*Minority & 6049 & .12 & .32 & 0 & 1 \\
\hline ElectionYear*Recand & 5923 & .21 & .40 & 0 & 1 \\
\hline ElectionYear*NoRecand & 5923 & .05 & .22 & 0 & 1 \\
\hline YearLegElection & 6056 & .36 & .48 & 0 & 1 \\
\hline
\end{tabular}

Sources: DGAL, OCDE, STAPE and municipal official accounts.

Note: The budget balance, the expenditures and the transfers are always expressed in thousands of Portuguese escudos (at 1995 prices) per capita. 
Table 2: Political Business Cycles in Local Finances

\begin{tabular}{|c|c|c|c|c|}
\hline & $\begin{array}{l}\text { Budget } \\
\text { Balance }\end{array}$ & $\begin{array}{c}\text { Total } \\
\text { Expenditures }\end{array}$ & $\begin{array}{c}\text { Capital } \\
\text { Expenditures }\end{array}$ & $\begin{array}{c}\text { Investment } \\
\text { Expenditures }\end{array}$ \\
\hline BudgetBalance (-1) & $\begin{array}{c}.126 \\
(4.36)^{* * *}\end{array}$ & & & \\
\hline TotExp (-1) & & $\begin{array}{c}.445 \\
(8.59)^{* * *}\end{array}$ & & \\
\hline CapExp (-1) & & & $\begin{array}{c}.279 \\
(9.31)^{* * *}\end{array}$ & \\
\hline $\operatorname{InvExp}(-1)$ & & & & $\begin{array}{c}.324 \\
(10.9)^{* * *}\end{array}$ \\
\hline $\operatorname{InvExp}(-2)$ & & & & $\begin{array}{l}-.036 \\
(-1.45)\end{array}$ \\
\hline TotTransf & & $\begin{array}{c}.537 \\
(6.41)^{* * *}\end{array}$ & & \\
\hline CapTransf & & & $\begin{array}{c}.845 \\
(15.5)^{* * *}\end{array}$ & $\begin{array}{c}.802 \\
(23.9)^{* * *}\end{array}$ \\
\hline ElectionYear & $\begin{array}{c}-.860 \\
(-1.90)^{*}\end{array}$ & $\begin{array}{l}1.787 \\
(1.83)^{*}\end{array}$ & $\begin{array}{c}1.138 \\
(3.53)^{* * *}\end{array}$ & $\begin{array}{c}2.170 \\
(6.16)^{* * *}\end{array}$ \\
\hline Right & $\begin{array}{c}-.748 \\
(-1.84)^{*}\end{array}$ & $\begin{array}{l}-2.464 \\
(-1.95)^{*}\end{array}$ & $\begin{array}{c}1.314 \\
(2.02)^{* *}\end{array}$ & $\begin{array}{l}.495 \\
(.90)\end{array}$ \\
\hline$\%$ Pop $<15$ & $\begin{array}{c}.269 \\
(3.58)^{* * *}\end{array}$ & $\begin{array}{c}-1.229 \\
(-6.66)^{* * *}\end{array}$ & $\begin{array}{l}-.102 \\
(-1.04)\end{array}$ & $\begin{array}{c}.315 \\
(3.61)^{* * *}\end{array}$ \\
\hline$\%$ Pop $>65$ & $\begin{array}{c}-.123 \\
(-1.74)^{*}\end{array}$ & $\begin{array}{l}.051 \\
(.22)\end{array}$ & $\begin{array}{l}-.053 \\
(-.43)\end{array}$ & $\begin{array}{l}-.025 \\
(-.23)\end{array}$ \\
\hline PopDens & $\begin{array}{l}-.0002 \\
(-.84)\end{array}$ & $\begin{array}{l}.001 \\
(.97)\end{array}$ & $\begin{array}{l}.0005 \\
(.70)\end{array}$ & $\begin{array}{l}.0009 \\
(1.19)\end{array}$ \\
\hline Coastline & $\begin{array}{l}.013 \\
(.04)\end{array}$ & $\begin{array}{c}5.029 \\
(3.00)^{* * *}\end{array}$ & $\begin{array}{c}2.458 \\
(3.03)^{* * *}\end{array}$ & $\begin{array}{c}1.893 \\
(2.55)^{* *}\end{array}$ \\
\hline PopCat & $\begin{array}{c}-.534 \\
(-1.59) \\
\end{array}$ & $\begin{array}{c}-3.244 \\
(-2.47)^{* * *} \\
\end{array}$ & $\begin{array}{c}-.849 \\
(-1.20) \\
\end{array}$ & $\begin{array}{c}-.003 \\
(-.005) \\
\end{array}$ \\
\hline No. Observations & 5397 & 5246 & 5298 & 4858 \\
\hline No. Municipalities & 275 & 275 & 275 & 275 \\
\hline
\end{tabular}

Sources: DGAL, STAPE and OCDE.

Notes: - Estimations of system-GMM linear models for panel data (which combine the equations in first-differences with the equations in levels), using the econometric software PcGive 10.2;

- two-step results using robust standard errors corrected for finite samples;

- T-statistics are between parentheses. Significance level for which the null hypothesis is rejected: ***, $1 \%$; **, $5 \%, \mathrm{e}^{*}, 10 \%$;

- The "Sargan test" is the test for the validity of the over-identifying restrictions;

- The hypothesis of second order autocorrelation of the residuals was always rejected and Sargan tests never rejected the validity of the over-identifying restrictions. 
Table 3: Political Business Cycles in Investment Expenditures

\begin{tabular}{|c|c|c|c|c|c|}
\hline InvExp & 1 & 2 & 3 & 4 & 5 \\
\hline $\operatorname{InvExp}(-1)$ & $\begin{array}{c}.326 \\
(11.1)^{* * *}\end{array}$ & $\begin{array}{c}.322 \\
(10.8)^{* * *}\end{array}$ & $\begin{array}{c}.350 \\
(10.5)^{* * *}\end{array}$ & $\begin{array}{c}.326 \\
(11.0)^{* * *}\end{array}$ & $\begin{array}{c}.331 \\
(11.2)^{* * *}\end{array}$ \\
\hline $\operatorname{InvExp}(-2)$ & $\begin{array}{c}-.035 \\
(-1.39)\end{array}$ & $\begin{array}{c}-.037 \\
(-1.50)\end{array}$ & $\begin{array}{c}-.052 \\
(-2.06)^{* *}\end{array}$ & $\begin{array}{l}-.020 \\
(-.78)\end{array}$ & $\begin{array}{c}-.029 \\
(-1.06)\end{array}$ \\
\hline CapTransf & $\begin{array}{c}.800 \\
(23.9)^{* * *}\end{array}$ & $\begin{array}{c}.803 \\
(23.8)^{* * *}\end{array}$ & $\begin{array}{c}.770 \\
(18.5)^{* * *}\end{array}$ & $\begin{array}{c}.792 \\
(23.4)^{* * *}\end{array}$ & $\begin{array}{c}.791 \\
(23.4)^{* * *}\end{array}$ \\
\hline Right & $\begin{array}{c}.998 \\
(1.75)^{*}\end{array}$ & $\begin{array}{l}.563 \\
(.99)\end{array}$ & $\begin{array}{c}.614 \\
(1.10)\end{array}$ & $\begin{array}{l}.415 \\
(.76)\end{array}$ & $\begin{array}{l}.456 \\
(.83)\end{array}$ \\
\hline ElectionYear*Right & $\begin{array}{c}1.154 \\
(2.68)^{* * *}\end{array}$ & & & & \\
\hline ElectionYear*Left & $\begin{array}{c}3.211 \\
(6.21)^{* * *}\end{array}$ & & & & \\
\hline Majority & & $\begin{array}{c}.926 \\
(1.96)^{* *}\end{array}$ & & & \\
\hline ElectionYear*Majority & & $\begin{array}{c}2.079 \\
(3.96)^{* * *}\end{array}$ & & & \\
\hline ElectionYear*Minority & & $\begin{array}{c}2.294 \\
(5.71)^{* * *}\end{array}$ & & & \\
\hline ElectionYear*Recand & & & $\begin{array}{c}2.263 \\
(5.91)^{* * *}\end{array}$ & & \\
\hline ElectionYear*NoRecand & & & $\begin{array}{c}1.567 \\
(2.17)^{* *}\end{array}$ & & \\
\hline ElectionYear & & & & $\begin{array}{c}3.222 \\
(8.24)^{* * *}\end{array}$ & $\begin{array}{c}3.584 \\
(8.66)^{* * *}\end{array}$ \\
\hline YearBeforeElection & & & & $\begin{array}{c}2.406 \\
(8.03)^{* * *}\end{array}$ & $\begin{array}{c}2.896 \\
(7.72)^{* * *}\end{array}$ \\
\hline YearLegElection & & & & & $\begin{array}{c}.824 \\
(2.29)^{* *} \\
\end{array}$ \\
\hline No. Observations & 4858 & 4858 & 4806 & 4858 & 4858 \\
\hline No. Municipalities & 275 & 275 & 275 & 275 & 275 \\
\hline
\end{tabular}

Sources: DGAL, STAPE, OCDE and INE.

Notes:- Estimations of system-GMM linear models for panel data (which combine the equations in first-differences with the equations in levels), using the econometric software PcGive 10.2;

- The coefficients and t-statistics for the five control variables $\% P o p<15, \% P o p>65$, PopDens, Coastline and PopCat (included in all estimations) are not shown in order to economize space;

- two-step results using robust standard errors corrected for finite samples;

- T-statistics are between parentheses. Significance level for which the null hypothesis is rejected: ***, $1 \%$; **, $5 \%, \mathrm{e}^{*}, 10 \%$;

- The "Sargan test" is the test for the validity of the over-identifying restrictions;

- The hypothesis of second order autocorrelation of the residuals was always rejected and Sargan tests never rejected the validity of the over-identifying restrictions. 
Table 4: Political Business Cycles in Investment Expenditures Components

\begin{tabular}{|c|c|c|c|c|c|c|c|}
\hline & $\begin{array}{c}\text { Acquisition } \\
\text { of Land }\end{array}$ & Housing & $\begin{array}{c}\text { Other } \\
\text { Buildings }\end{array}$ & $\begin{array}{l}\text { Miscellaneous } \\
\text { Constructions }\end{array}$ & $\begin{array}{c}\text { Transportation } \\
\text { Material }\end{array}$ & $\begin{array}{l}\text { Machinery and } \\
\text { Equipment }\end{array}$ & $\begin{array}{c}\text { Other } \\
\text { Investments }\end{array}$ \\
\hline Dep.Variable (-1) & $\begin{array}{c}.227 \\
(2.75)^{* * *}\end{array}$ & $\begin{array}{c}.417 \\
(8.91)^{* * *}\end{array}$ & $\begin{array}{c}.374 \\
(9.62)^{* * *}\end{array}$ & $\begin{array}{c}.289 \\
(9.69)^{* * *}\end{array}$ & $\begin{array}{c}.083 \\
(2.77)^{* * *}\end{array}$ & $\begin{array}{c}.247 \\
(5.19)^{* * *}\end{array}$ & $\begin{array}{c}.098 \\
(2.71)^{* * *}\end{array}$ \\
\hline Dep. Variable (-2) & & $\begin{array}{c}-.139 \\
(-3.78)^{* * *}\end{array}$ & & $\begin{array}{c}-.082 \\
(-3.42)^{* * * *}\end{array}$ & & & $\begin{array}{c}.057 \\
(2.07)^{* *}\end{array}$ \\
\hline CapTransf & $\begin{array}{c}.024 \\
(4.72)^{* * *}\end{array}$ & $\begin{array}{c}.031 \\
(3.48)^{* * *}\end{array}$ & $\begin{array}{c}.141 \\
(7.26)^{* * *}\end{array}$ & $\begin{array}{c}.594 \\
(13.7)^{* * *}\end{array}$ & $\begin{array}{l}.002 \\
(.61)\end{array}$ & $\begin{array}{c}.030 \\
(5.68)^{* * *}\end{array}$ & $\begin{array}{c}.020 \\
(4.04)^{* * *}\end{array}$ \\
\hline ElectionYear & $\begin{array}{c}-.099 \\
(-1.54)\end{array}$ & $\begin{array}{l}.094 \\
(.63)\end{array}$ & $\begin{array}{c}.749 \\
(3.83)^{* * *}\end{array}$ & $\begin{array}{c}2.396 \\
(6.60)^{* * *}\end{array}$ & $\begin{array}{c}-.109 \\
(-2.77)^{* * *}\end{array}$ & $\begin{array}{c}-.137 \\
(-2.60)^{* * *}\end{array}$ & $\begin{array}{c}.142 \\
(2.33)^{* *}\end{array}$ \\
\hline YearBeforeElection & $\begin{array}{c}.057 \\
(1.00)\end{array}$ & $\begin{array}{l}.076 \\
(.61)\end{array}$ & $\begin{array}{l}.178 \\
(.99)\end{array}$ & $\begin{array}{c}1.387 \\
(4.70)^{* * *}\end{array}$ & $\begin{array}{c}.053 \\
(1.44)\end{array}$ & $\begin{array}{l}-.046 \\
(-.87)\end{array}$ & $\begin{array}{c}.095 \\
(1.62)\end{array}$ \\
\hline Right & $\begin{array}{c}.221 \\
(3.18)^{* * *}\end{array}$ & $\begin{array}{l}.049 \\
(.27)\end{array}$ & $\begin{array}{l}-.041 \\
(-.17)\end{array}$ & $\begin{array}{c}1.013 \\
(1.74)^{*}\end{array}$ & $\begin{array}{c}-.115 \\
(-1.89)^{*}\end{array}$ & $\begin{array}{c}-.279 \\
(-3.78)^{* * *}\end{array}$ & $\begin{array}{l}-.068 \\
(-.77)\end{array}$ \\
\hline No. Observations & 4805 & 4230 & 4083 & 3807 & 4080 & 4813 & 3713 \\
\hline No. Municipalities & 275 & 275 & 275 & 275 & 275 & 275 & 275 \\
\hline
\end{tabular}

Sources: DGAL, STAPE, OCDE and INE.

Notes: - Estimations of system-GMM linear models for panel data (which combine the equations in first-differences with the equation in levels), using the econometric software PcGive 10.2;

- The coefficients and t-statistics for the control variables $\%$ Pop $<15, \%$ Pop $>65$, PopDens, Coastline and PopCat (included in all estimations) are not shown in order to economize space;

- two-step results using robust standard errors corrected for finite samples;

- T-statistics are between parentheses. Significance level for which the null hypothesis is rejected: ***, 1\%; **, 5\%, e *, 10\%;

- The "Sargan test" is the test for the validity of the over-identifying restrictions;

- The hypothesis of second order autocorrelation of the residuals was always rejected and Sargan tests never rejected the validity of the over-identifying restrictions. 
Table 5: Sub-components of Investment Expenditures for which there is evidence of

Political Business Cycles

\begin{tabular}{lcccc}
\hline Component: & $\begin{array}{c}\text { Other } \\
\text { Buildings }\end{array}$ & \multicolumn{2}{c}{ Miscellaneous Constructions } \\
Sub-component: & Other & $\begin{array}{c}\text { Overpasses, streets } \\
\text { and complementary } \\
\text { works }\end{array}$ & Rural roads & Other \\
\hline Dep. Variable (-1) & .303 & .389 & .384 & .359 \\
& $(6.01)^{* * *}$ & $(4.65)^{* * *}$ & $(10.4)^{* * *}$ & $(6.03)^{* * *}$ \\
CapTransf & .065 & .094 & .146 & .167 \\
& $(4.26)^{* * *}$ & $(3.93)^{* * *}$ & $(5.60)^{* * *}$ & $(5.68)^{* * *}$ \\
ElectionYear & .633 & .653 & .970 & 1.477 \\
& $(4.12)^{* * *}$ & $(3.38)^{* * *}$ & $(4.04)^{* * *}$ & $(5.87)^{* * *}$ \\
YearBeforeElection & .518 & .468 & .169 & 1.099 \\
& $(3.94)^{* * *}$ & $(2.90)^{* * *}$ & $(1.03)$ & $(4.79)^{* * *}$ \\
Right & .023 & .336 & .316 & -.268 \\
& $(.13)$ & $(1.51)$ & $(.78)$ & $(-.99)$ \\
\hline No. Observations & 4080 & 4801 & 4809 & 3682 \\
No. Municipalities & 275 & 275 & 275 & 275 \\
\hline
\end{tabular}

Sources: DGAL, STAPE, OCDE and INE.

Notes: - Estimations of system-GMM linear models for panel data (which combine the equations in firstdifferences with the equation in levels), using the econometric software PcGive 10.2;

- The coefficients and t-statistics for the control variables \%Pop<15, \%Pop $>65$, PopDens, Coastline and PopCat (included in all estimations) are not shown in order to economize space;

- two-step results using robust standard errors corrected for finite samples;

- T-statistics are between parentheses. Significance level for which the null hypothesis is rejected: ***, $1 \%$; **, $5 \%, \mathrm{e} *, 10 \%$;

- The "Sargan test" is the test for the validity of the over-identifying restrictions;

- The hypothesis of second order autocorrelation of the residuals was always rejected and Sargan tests never rejected the validity of the over-identifying restrictions. 